\title{
IS FUNCTIONAL OUTCOME BETTER AFTER ARTHROPLASTY FOR TROCHANTERIC FRACTURES IN OLDER ADULTS?
}

\author{
O RESULTADO FUNCIONAL É MELHOR DEPOIS DA \\ ARTROPLASTIA PARA FRATURAS TROCANTÉRICAS EM IDOSOS?
}

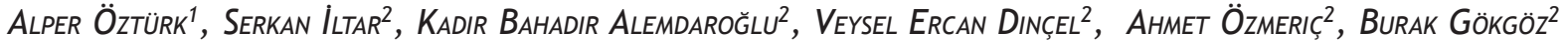 \\ 1. Department of Orthopaedics, Baskent University, Konya Research Center. \\ 2. Department of Orthopaedics, Ankara Training and Research Hospital, University of Health Sciences.
}

\begin{abstract}
Objectives: This article evaluated functional recovery and mortality after surgery to repair trochanteric fracture with regard to treatment technique through one year of follow-up. Method: Eighty consecutive patients with trochanteric fractures were divided into two groups according to treatment technique (osteosynthesis and arthroplasty). We evaluated patient data including age, sex, time to surgery, total hospital stay, transfusion volume, and functional status according to FIM (Functional Independence Measure) scores. Scores for FIM were assessed three times: prior to fracture, six months after surgery, and one year after surgery. Results: Patients who received osteosynthesis had shorter hospital stays than arthroplasty patients. The arthroplasty group had significantly higher functional independence six months after surgery, while no difference was detected one year after surgery. Patient age, transfusion volume, and FIM scores were detected as significant predictors of mortality. Conclusion: Trochanteric fractures lead to unavoidable functional loss, although this can be reduced in the short term by treating with arthroplasty instead of osteosynthesis. Age, transfusion and functional situation predict one-year mortality for patients with trochanteric fractures. The patient's functional situation must be considered when choosing treatment for trochanteric fractures in order to reduce patient morbidity. Level of Evidence II; Therapeutic prospective study.
\end{abstract}

Keywords: Hip fractures. Arthroplasty. Fracture fixation, internal. Rehabilitation.

\section{RESUMO}

Objetivo: Este artigo avaliou a recuperação funcional e a mortalidade após cirurgia de fratura do quadril com relação à técnica de tratamento durante um ano de acompanhamento. Método: Oitenta pacientes consecutivos com fraturas trocantéricas foram divididos em dois grupos, de acordo com a técnica de tratamento (osteossintese e artroplastia). Avaliamos os dados dos pacientes quanto a idade, sexo, tempo até a cirurgia, estadia hospitalar total, volume de transfusão e estado funcional de acordo com a pontuação da MIF (Medida de Independência Funcional). A MIF foi avaliada três vezes: antes da fratura, seis meses e um ano após a cirurgia. Resultados: Os pacientes submetidos à osteossíntese tiveram menor tempo de hospitalização do que os pacientes de artroplastia. O grupo artroplastia teve independência funcional significativamente maior seis meses depois da cirurgia, enquanto nenhuma diferença foi detectada um ano após a cirurgia. Idade, volume da transfusão e a pontuação MIF dos pacientes foram detectadas como preditores importantes da mortalidade. Conclusão: As fraturas trocantéricas levam à perda funcional inevitável, embora ela possa ser reduzida a curto prazo com a artroplastia ao invés da osteossíntese. A idade, a transfusão e a situação funcional são preditores significativos de mortalidade em um ano em pacientes com fraturas trocantéricas. A situação funcional dos pacientes deve ser considerada ao escolher o tratamento de fraturas trocantéricas para reduzir a morbidade dos pacientes. Nível de Evidência II; Estudo prospectivo terapêutico.

Descritores: Fratura do quadril. Artroplastia. Fixação interna de fraturas. Reabilitação.

Citation: Öztürk A, İltar S, Alemdaroğlu KB, Dinçel VE, Özmeriç A, Gökgöz B. Is functional outcome better after arthroplasty for trochanteric fractures in older adults? Acta Ortop Bras. [online]. 2018;26(1):8-10. Available from URL: http://www.scielo.br/aob.

\section{INTRODUCTION}

As life expectancy grows, the number of hip fractures has been increasing. Since hip fractures are associated with high morbidity and mortality, ${ }^{1,2}$ the social and economic burden of hip fractures is also on the rise. ${ }^{3,4}$ Conservative treatment is generally not preferred and is reserved for debilitated patients because of critical complications. ${ }^{5}$
Although advances in anesthesia, surgical techniques, and implant designs have designated surgery as the standard treatment, no exact consensus has been reached as to which treatment is best. Even though the type of surgical treatment may vary, postoperative treatment goals are the same, namely to restore the patient to his or her pre-injured functional state. ${ }^{6,7}$

All authors declare no potential conflict of interest related to this article.

Work conducted at the Ankara Training and Research Hospital, Ankara, Turkey.

Correspondence: Başkent University, Konya Research Center, Department of Orthopaedics and Traumatology, Selçuklu, Konya Turkey. dr_alperozturk@yahoo.com 
The main objectives of this study were 1) to explore functional recovery after trochanteric fracture surgery with regard to treatment technique, and 2) to evaluate predictive factors for early mortality.

\section{METHODS}

This prospective observational study included 80 patients 60 years of age or older who were admitted to the hospital for intertrochanteric fractures and underwent surgery between September 2012 and May 2014. The study was performed with the consent of the local ethics committee (2014:4688) and after all patients signed the informed consent form.

Patients with intertrochanteric fractures were divided into two groups: group I (osteosynthesis) was treated with a proximal femoral nail, and group II (arthroplasty) was treated with arthroplasty. Each group included 40 consecutive patients.

Arthroplasty surgeries were performed thorough a postero-lateral incision in lateral decubitus position and cemented femoral stems (Bi-Metric Primary Calcar Replacement, Biomet, South Wales, UK) were implanted. Nailing surgeries were performed on a fracture table in supine position. The same proximal femoral nail (Proximal Femoral Nail Antirotation, Synthes $\mathrm{GmbH}$, Oberdorf, Switzerland)) was used in all patients.

All patients only received surgery after coexisting medical conditions were stabilized and a pre-operative anesthesia consultation was performed. All patients received thromboprophylaxis with low molecular weight heparin and antibiotic prophylaxis with first-generation cephalosporin 30 minutes prior to surgery.

Patients who were treated with a femoral nail were allowed to bear weight after surgery as tolerated, and full weight-bearing was permitted in arthroplasty patients after drain removal. All patients were evaluated 15 days, 1 month, 6 months, and 1 year after surgery.

The following data were recorded for each patient during the hospital stay: age, sex, time to operation, total hospital stay, total blood transfusion during hospital stay, and hemoglobin levels at admittance to the emergency department. Functional outcomes were assessed using the Functional Independence Measure (FIM) for three different times: prior to fracture, six months after surgery, and one year after surgery. This evaluation was performed via a face-to-face interview with the patient; the FIM prior to fracture was determined during the hospital stay. All patients were asked to return to the hospital for the functional evaluation six months and one year after surgery.

\section{Statistics analysis}

The statistical analysis was performed using SPSS version 20.0 for Windows (IBM SPSS Inc., NY USA). The baseline characteristics of the patients and clinical outcomes such as age, length of stay, and FIM scores were summarized as means and standard deviations. Categorical variables such as sex were summarized as frequencies and percentages. Each variable was analyzed for normal distribution using the Kolmogrov-Smirnov test and groups were compared using Students t-test and the chi-square test. The correlation between mortality and independent variables was analyzed using Spearman's correlation analysis. P-values less than 0.05 were considered significant.

\section{RESULTS}

Of the 80 patients admitted, 42 were females and 38 were males, with a mean age of 80.2 years (60-94). The mean follow-up period was 18 months. No difference was observed between groups with regard to age or sex. (Table 1 )
The mean total hospital stay was 12.3 days for group I and 14.65 days for group II $(p=0.04)$. The mean period from fracture to surgery was 5.3 days for group I and 6.1 days for group II $(p=0.249)$. (Table 1) Mean hemoglobin on admittance to hospital was $11.9 \mathrm{mg} / \mathrm{dl}$ in group I and $11.6 \mathrm{mg} / \mathrm{dl}$ in group II ( $\mathrm{p}=0.314)$. (Table 1) The mean blood transfusion volume required during the hospital stay was 0.95 units for group I and 1.25 units for group II. (Table 2) Although the patients who were treated with arthroplasty required a slightly greater transfusion volume, the difference was not significant $(p=0.325)$. At the one-year follow-up, 30 patients had died (37.5\%): 14 patients in group I (35\%) and 16 in group II (40\%). There was no significant difference in one-year mortality between groups $(p=0.644)$. Furthermore, age, blood transfusion during the hospital stay, and FIM had a significant correlation with mortality; patient FIM score had the strongest correlation with mortality. (Table 2)

The mean FIM value prior to fracture was $105.5 \pm 20.5$ in group I and $104.9 \pm 17.3$ in group $\|(p=0.381)$. Six months after surgery, mean FIM values were $84.7 \pm 27.1$ and $92.9 \pm 20.2$ in groups I and II, respectively. Group II had significantly higher FIM at six months $(p=0.04)$. One year after surgery, the mean FIM values were $97.7 \pm 28.7$ for group I and 93.1 \pm 22.8 for group II, and there was no significant difference one year after surgery $(p=0.476)$. (Table 3$)$

\begin{tabular}{|c|c|c|c|c|c|c|c|}
\hline \multirow[b]{2}{*}{ Parameter } & \multicolumn{3}{|c|}{ Osteosynthesis Group } & \multicolumn{3}{|c|}{ Arthroplasty Group } & \multirow[t]{2}{*}{$p^{*}$} \\
\hline & Mean & SD & \begin{tabular}{|l|} 
Range \\
\end{tabular} & Mean & SD & Range & \\
\hline \multicolumn{8}{|l|}{ Sex } \\
\hline Female & 17 & & & 25 & & & \multirow{2}{*}{0.07} \\
\hline Male & 23 & & & 15 & & & \\
\hline Age (years) & 79 & 10.1 & $60-94$ & 81.4 & 7.2 & $62-93$ & 0.213 \\
\hline $\begin{array}{l}\text { Time to Surgery } \\
\text { (days) }\end{array}$ & 5.3 & 2.5 & $1-13$ & 6.1 & 3.3 & $1-16$ & 0.249 \\
\hline Total Hospital Stay (days) & 12.3 & 4 & $4-23$ & 14.6 & 5.9 & $4-32$ & 0.04 \\
\hline $\begin{array}{c}\text { Hemoglobin on } \\
\text { Admittance (mg/dl) }\end{array}$ & 11.9 & 1.3 & $9.9-15.9$ & 11.6 & 1.5 & $\begin{array}{l}7.7- \\
15.6\end{array}$ & 0.314 \\
\hline Blood Transfusion (units) & 0.95 & 1.4 & $0-6$ & 1.25 & 1.2 & $0-5$ & 0.325 \\
\hline
\end{tabular}

\begin{tabular}{c|c|c|c|c} 
Table 2. Patient mortality. \\
\hline Mortality & Osteosynthesis & Arthroplasty & $\mathbf{p}$ & Total \\
\hline 6 Months & $13(32.5 \%)$ & $14(35 \%)$ & $0.813^{*}$ & $27(33.8 \%)$ \\
\hline 1 Year & $14(35 \%)$ & $16(40 \%)$ & $0.644^{*}$ & $30(37.5 \%)$ \\
\hline Mortality Correlation & $\begin{array}{c}\text { Correlation }_{\text {Coefficient }^{* *}} \\
\text { Patient Age }\end{array}$ & $\mathbf{p}$ & & \\
\hline Sex & 0.226 & 0.001 & & \\
\hline Time to Surgery & 0.102 & 0.266 & & \\
\hline Total Hospital Stay & -0.023 & 0.804 & & \\
\hline Hemoglobin on Admittance & -0.145 & 0.835 & & \\
\hline Transfusion & 0.223 & 0.114 & & \\
\hline FIM before fracture & -0.472 & 0.04 & & \\
\hline Ching & & & & \\
\hline
\end{tabular}

*: Chi-square test **: Spearman's Rho.

Table 3. Functional Independence Measure scores over 1 year.

\begin{tabular}{c|c|c|c|c|c|c|c}
\hline & \multicolumn{3}{|c|}{ Osteosynthesis } & \multicolumn{3}{c|}{ Arthroplasty } & \\
\hline & Mean & SD & Range & Mean & SD & Range & $\mathbf{p}^{*}$ \\
\hline FIM prior to fracture & 105.5 & 20.5 & $58-126$ & 104.9 & 17.3 & $72-126$ & 0.381 \\
\hline FIM 6 months after surgery & 84.7 & 27.1 & $44-126$ & 92.9 & 20.2 & $60-126$ & 0.04 \\
\hline FIM 1 year after surgery & 97.7 & 28.7 & $44-126$ & 93.1 & 22.8 & $45-126$ & 0.476 \\
\hline *: t-test. & \multicolumn{9}{|c|}{}
\end{tabular}




\section{DISCUSSION}

This is the first study to report functional progress in patients with trochanteric fracture with regard to treatment method. The results of this study clearly indicate that serious functional regression is unavoidable in treating patients with trochanteric fractures during the first year.

We used FIM scores to evaluate patient function in this study; the FIM evaluates patients with regard to disability and care burden, and predicts how much assistance is required for patients to carry out daily living activities. The validity of the FIM was evaluated by Young et al.; it was described as a valid indicator for the functional status of patients recovering from hip fracture surgery and is also reported to be feasible for longitudinal studies. ${ }^{8}$

This study demonstrated that arthroplasty provides higher functional independence in early results when compared to osteosynthesis. This finding suggests that osteosynthesis cannot restore serious functional loss in early stages, while arthroplasty can provide a certain level of functional independence over even a short time. As Bonnevialle et al. ${ }^{9}$ reported, arthroplasty provides better functional results in six months. Fracture treatment involving osteosynthesis could cause weight-bearing problems that result as functional loss in elderly patients with hip fracture. This functional loss was recovered within one year of surgery, and no functional differences were seen between patients treated with arthroplasty or osteosynthesis. Many reports indicate that the functional outcomes for arthroplasty and osteosynthesis are similar after 1 to 2 years of follow-up, as we concluded in this present study. ${ }^{10,11}$ Because this study demonstrated a powerful relation between mortality and the patient's functional status, we believe that arthroplasty could be a good treatment choice for patients with trochanteric fractures and low functional status who would not tolerate serious functional loss in a short time period. However, osteosynthesis treatment is preferable for patients with adequate daily functional status because of its advantages such as preserving the patient's own bone, less invasive surgery, a shorter hospital stay, and lower treatment costs.

Although surgery within the first 24 hours has been reported to reduce rates of non-union, length of hospital stay, mortality, and complications, ${ }^{12-14}$ early surgery is not always feasible due to medical comorbidities. ${ }^{15}$ In our study, nearly 6 days were needed between fracture and surgery in order to resolve pre-operative challenges related to comorbidities.

In contrast with the study by Shokoohi et al., ${ }^{16}$ we found a relationship between transfusion and mortality in this study. One-year mortality for hip fractures has been reported to be around $12 \%$ and $37 \% .{ }^{17,18}$ In this study, the one-year mortality rate was $37 \%$, and no difference was observed regarding surgical technique. Although all the arthroplasties involved the cemented technique, no significant difference in mortality was detected between arthroplasty and osteosynthesis. The predictors for one-year mortality in this study were patient age, transfusion, and functional score. Therefore, the patient's functional situation prior to hip fracture may guide the surgeon when selecting the treatment for trochanteric fractures in older adults.

\section{CONCLUSION}

This current study demonstrated that the strongest predictor of mortality in patients with trochanteric fracture are age, transfusion volume, and functional score. Functional loss is unavoidable in patients regardless of treatment choice, but arthroplasty provides better functional results than osteosynthesis in early outcomes. This should be considered particularly in elderly patients with trochanteric fractures and low function who would not tolerate serious functional loss.

AUTHORS’ CONTRIBUTIONS: Each author made significant individual contributions to this manuscript. AÖ (0000-0003-2986-4083) * drafting the article and revision. Si (0000-0002-1027-7885)* and ED (0000-0001-5605-7514)* performed the surgeries; KBA (0000-0002-5922-9921)*: data analysis, drafting the articles and also the entire intellectual concept of the article; AhÖ (0000-0001-5398-446X)*: statistical analysis, surgeries, and review of the article; BG (0000-0003-0758-5382)* data collection and analysis and surgeries. * ORCID (Open Researcher and Contributor ID).

\section{REFERENCES}

1. Wolinsky FD, Fitzgerald JF, Stump TE. The effect of hip fracture on mortality, hospitalization, and functional status: a prospective study. Am J Public Health. 1997;87(3):398-403.

2. Bentler SE, Liu L, Obrizan M, Cook EA, Wright KB, Geweke JF, et al. The aftermath of hip fracture: discharge placement, functional status change, and mortality. Am J Epidemiol. 2009;170(10):1290-9.

3. LaVelle DG, Canale ST. Fractures of hip. In: Canale ST. Campbell's operative orthopaedics. 10th. Philadelphia; Mosby Press; 2003. p. 2873.

4. Huddleston JM, Whitford KJ. Medical care of elderly patients with hip fractures. Mayo Clin Proc. 2001;76(3):295-8.

5. Handoll HH, Parker MJ. Conservative versus operative treatment for hip fractures in adults. Cochrane Database Syst Rev. 2008;(3):CD000337.

6. Huusko TM, Karppi P, Avikainen V, Kautiainen H, Sulkava R. Randomised, clinically controlled trial of intensive geriatric rehabilitation in patients with hip fracture: subgroup analysis of patients with dementia. BMJ. 2000;321(7269):1107-11.

7. Aguiar FJ, Nemer DS, Leme LEG. Estado nutricional e evolução de cirurgias ortopédicas de urgência em idosos. Acta Ortop Bras. 2011;19(5):293-8.

8. Young Y, Fan MY, Hebel JR, Boult C. Concurrent validity of administering the functional independence measure (FIM) instrument by interview. Am J Phys Med Rehabil. 2009;88(9):766-70.

9. Bonnevialle P, Saragaglia D, Ehlinger M, Tonetti J, Maisse N, Adam P, et al. Trochanteric locking nail versus arthroplasty in unstable intertrochanteric fracture in patients aged over 75 years. Orthop Traumatol Surg Res. 2011;97(Suppl 6):S95-100.

10. Stappaerts KH, Deldycke J, Broos PL, Staes FF, Rommens PM, Claes P. Treatment of unstable peritrochanteric fractures in elderly patients with a compression hip screw or with the Vandeputte (VDP) endoprosthesis: a prospective randomized study. J Orthop Trauma. 1995;9(4):292-7.

11. Lu XD, Wang B, Xu W, Zhang Q, Han D, Zhao YT. Comparison of calcarreplacement arthro plasty and Intertan nail in treatment of intertrochanteric fracture in the aged]. Zhonghua Yi Xue Za Zhi. 2016;96(31):2466-71.

12. Koval KJ, Skovron ML, Aharonoff GB, Zuckerman JD. Predictors of functional recovery after hip fracture in the elderly. Clin Orthop Relat Res. 1998;(348):22-8

13. Bottle A, Aylin P. Mortality associated with delay in operation after hip fracture: observational study. BMJ. 2006;332(7547):947-51.

14. Ryan DJ, Yoshihara H, Yoneoka D, Egol KA, Zuckerman JD. Delay in hip fracture surgery: an analysis of patient-specific and hospital-specific risk factors. J Orthop Trauma. 2015;29(8):343-8.

15. Makridis KG, Karachalios T, Kontogeorgakos VA, Badras LS, Malizos KN. The effect of osteoporotic treatment on the functional outcome, re-fracture rate, quality of life and mortality in patients with hip fractures: a prospective functional and clinical outcome study on 520 patients. Injury. 2015;46(2):378-83.

16. Shokoohi A, Stanworth S, Mistry D, Lamb S, Staves J, Murphy MF. The risks of red cell transfusion for hip fracture surgery in the elderly. Vox Sang. 2012;103(3):223-30.

17. Panula J, Pihlajamäki $H$, Mattila VM, Jaatinen $P$, Vahlberg $T$, Aarnio $P$, et al. Mortality and cause of death in hip fracture patients aged 65 or older: a population-based study. BMC Musculoskelet Disord. 2011;12:105.

18. Richmond J, Aharonoff GB, Zuckerman JD, Koval KJ. Mortality risk after hip fracture. J Orthop Trauma. 2003;17(1):53-6. 